\title{
COMMENTARIES
}

\section{Crisis communication and COVID-19 \\ Covering two Pacific tragedies with storytelling}

Commentary: Frontline journalism in the age of COVID-19 has posed particular challenges in dealing with personal risk, tackling an 'infodemic' of misinformation, and providing valuable news that can be used in vulnerable Pacific countries that have struggled with soaring infections and limited health infrastructure and resources. Five Pacific countries or territories have borne the brunt of the coronavirus pandemic - Fiji, French Polynesia, Guam, Papua New Guinea, and Timor-Leste. This article introduces two examples of public health storytelling in crisis communication, one being a pregnant Papua New Guinea woman who walked 25 kilometres to the nearest hospital—and died on reaching her destination; the other a pregnant Fijian nurse who died after battling COVID-19.

Keywords: communication ecology, coronavirus, COVID-19, covid journalism, crisis communication, health journalism, infodemic, journalism, media ecology, pandemic, public health, storytelling, vaccine hesitancy

\section{DAVID ROBIE}

Associate Editor, Pacific Journalism Review

OR JOURNALISTS from all corners of the globe, the COVID-19 coronavirus pandemic has proved a relentless news and current affairs story with multiple challenges. It has not just been a health story to cover, it has actually been an unprecedented existential assignment. Never ending.

One of the biggest challenges of all has been an 'infodemic' of misinformation and falsehoods peddled by many through social media postings which have contributed to a serious vaccine hesitancy problem in many countries, particularly where education is limited (Estella, 2020).

Another major challenge has been the personal risk for many journalists covering this pandemic that, according to arguably the most reliable public statistics monitor, the John Hopkins University Coronavirus Resource Centre 
(COVID-19 Dashboard, 2021) case tracker, had infected more than 207 million people and caused more than 4.3 million deaths globally at the time of writing.

A United Nations COVID-19 Response webpage cited several journalists on the frontline coverage during lockdowns, including the case of Reuters' chief photographer for the Benelux countries, Yves Herman, and his personal experience reporting almost daily for several months from hospitals, retirement homes, funeral services and morgues while 'wearing full protective gear' (UNRIC Brussels, 2021). Herman notes how this has been one of the rare news assignments that has an impact on almost everybody, including journalists:

Despite the risks, I felt it was really such an important subject to cover. To my knowledge, it is one of the only stories in the world, except perhaps the Second World War, which affects absolutely everyone. (Herman, cited by UNRIC Brussels, 2021)

Other journalists write of a personal responsibility to connect people with the 'resources they need to stay healthy', especially as in the early stages of the pandemic, COVID-19 was frequently not perceived as a serious global threat (Estella, 2020; Perreault \& Perreault, 2021; Robie \& Krishnamurthi, 2020). According to researchers Perreault and Perreault (2021), how journalists talk about covering COVID-19 'is informed by the larger conversation outside of the field of journalism'. Their study explores how journalists discursively constructed their media ecological relationships during the pandemic.

We argue that journalists working during COVID-19 discursively placed themselves in a vulnerable position within the communication ecology, despite their responsibilities to facilitate relationships. Journalists hence found their reporting difficult during the pandemic, in that the pandemic exacerbated weaknesses that have long existed within the ecology. (Perrault \& Perrault, 2021)

The researchers noted the difficulties that journalists faced working in COVID-19 conditions, such as interviewing people face-to-face, 'but using online video conferencing software like Zoom could mitigate the challenge' (Perrault \& Perrault, 2021). Writing in the introduction to their new book, COVID-19, Racism and Politicization: Media in the Midst of a Pandemic, co-authors Kalinga Seneviratne and Sundeep Muppidi write of how the logical thing would be for all humans to 'put aside their differences' and work towards resolving the crises globally in a united manner.

However, the COVID-19 pandemic has been the perfect storm in which international and domestic politics, misinformation, paranoia and media bias have contributed to an undermining of democratic and community 
values, and heightened fear and distrust among various sections of the population around the world. (Seneviratne \& Muppidi, 2021)

One of the agencies working in the Asia-Pacific region towards developing better COVID-19 and climate change reporting expertise through training and journalism collaborations is Internews and its portal Earth Journalism Network (https://earthjournalism.net/). According to its website, 'the root' of its strategy is to improve the health of information environments. As Internews explains, 'healthy information environments are defined by the presence of good, accurate, evidence-based information - information that everyone can access safe$l y$, that consumers know how to critically assess, and that is valued by communities and sustained by business models that work.' (Our strategy, n.d.) It adds that in healthy information environments, 'governments and businesses are accountable for keeping it that way'. The five elements of a strategic healthy information environment are teased out by Robie and Krishnamurthi (2020, p. 186). Examples of such strategic articles and initiatives include Abano and Kumar (2021) writing on the climate crisis threatening Pacific Island nations and a call for proposals on 'zoonotic diseases and One Health in the Asia-Pacific region' (Zoonotic diseases, 2021). About 20 grants would be available with an average of US $\$ 1,500$ being awarded to the successful proposals from both staff and freelance journalists. The network was seeking stories from the region that would engage audiences to better understand:

- the threat of potential spillovers and its causes;

- solutions that address the root causes of these threats;

- local and international efforts to improve ecological and human health, within the One Health framework.

Related to climate, Abano and Kumar note how Pacific countries are pressing for the adoption at COP26 in Glasgow in October of a separate standalone loss and damage finance mechanism so that it can address the financial need from vulnerable nations - such as Kiribati, Marshall Islands and Tuvalu-to relocate communities. They also cited an explanation of Lavetanalagi Seru, climate justice project officer of the Pacific Islands Climate Action Network (PICAN), who said:

We should be concerned with all climate impacts, including the slow onset disasters such as sea level rise, ocean acidification, and the warming ocean because we see many of our marine life of fish migrating to cooler waters and these have an effect on people, their security and livelihoods. (Abano \& Kumar, 2021)

Howes and Surandiran (2021) observed how for most of last year and until the early months of this year, the Pacific health narrative around COVID-19 
was mostly positive. True, there were damaging economic costs from the pandemic, but there were few cases and some countries were COVID-free. The five nations in the region that have borne the brunt of the pandemic are Fiji, Frenchruled Polynesia (Mā'ohi Nui), Guam, Papua New Guinea and Timor-Leste. On a population basis, French Polynesia had been the worst affected territory with 28,330 cases and 188 deaths (see Table 1), ahead of Papua New Guinea (17,806 $+192)$, Guam $(9,880+144)$. However, Fiji $(39,770$ cases +368 deaths $)$ has now outstripped them all with the exponential spread of the Delta variant since April 2021. Fiji has a strong vaccination programme in spite of a damaging anti-vaccination social media campaign. Assessing the available data, Howes and Suraniran argue:

The last few months have shown that keeping COVID-19 at bay is not an assured strategy. A low level of vaccinations not only increases pandemic risks but also delays borders reopening. Getting vaccination rates up must be a top priority for the Pacific, especially in Solomon Islands, PNG, Vanuatu and Timor-Leste.

\section{Table 1: Total COVID case count in five Pacific states, territories}

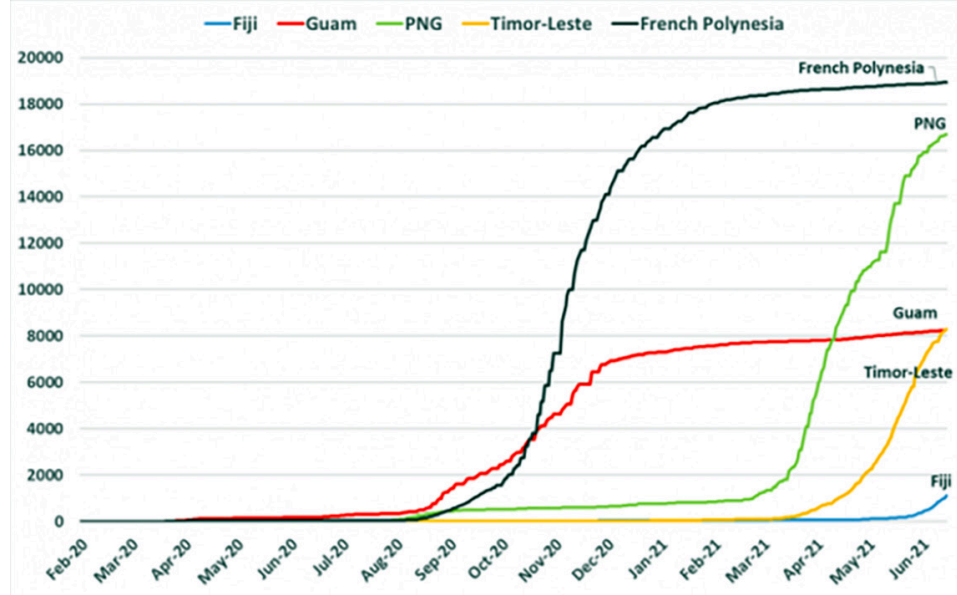

Note: The five countries and territories are Fiji, French Polynesia, Guam, PNG and Timor-Leste. Sources: Our World in Data for Fiji, Timor-Leste and PNG; World Health Organisation for French Polynesia; Centers for Disease Control and Prevention for Guam.

Accurate and compelling storytelling skills by truth-seeking journalists and civil society advocacy communicators are vital for effective crisis communication as outlined by Robie in his talanoa journalism model (2014, pp. 332-333; Robie \& Marbrook, 2020). Climate justice in the region is explored by Cass (2020). Two examples of tragic stories emerged as communication exemplars during the crisis month of July 2021, one in Papua New Guinea published on the independent 
blog of television journalist Scott Waide (Article 1), My Land My Country, and the other reported by a student journalist from the University of the South Pacific, Josefa Babitu, who is also editor of the student newspaper Wansolwara (Article 2). The PNG article, written by a health worker, outlined the 25 kilometre trek on foot of a pregnant woman to the nearest hospital through bush tracks, rugged roads and across a river before she died at the end of her journey; the Fiji article details the struggle of a pregnant nurse with COVID-19 before she also died.

\section{Impressive statistics for a student journalist}

At the time of writing Article 2, Babitu, editor of the University of the South Pacific student journalist newspaper Wansolwara, had received at least 5,934 reads of his Asia Pacific Report dispatch from Suva and more than 1,300 likes on social media, impressive statistics for a student journalist. This reflected a strong desire of Fijians to read about the experiences of fellow citizens suffering from COVID-19 in the hope that they might learn something. News that you can use. This was especially vital in the prevailing climate of Fiji disinformation, fake news, and a failure of authorities to give timely and practical information.

In their research study of journalists and their processes dealing with the daily challenges of the COVID-19 pandemic, Perreault and Perreault cite the facilitative role of journalism from the typology identified by Christians et al. (2010). According to this typology, 'journalists conceive of and operate their role given what they perceive their audience needs'. For example, when journalists operate in a storyteller role when mitigating coverage of 'dangerous actors'. The facilitative role draws on an understanding that the journalist is responsible to society and 'perhaps contributes to the public's decision making in a crisis'.

In a 2021 World Press Freedom Day editorial on May 3, Fiji Times editorin-chief Fred Wesley appealed for Pacific understanding of the role of journalists when speaking truth to power. Lamenting that sometimes journalists were misunderstood in Fiji, he warned:

In the face of the overwhelming COVID-19 pandemic, journalists, now more than ever, face huge challenges ... Faced with many obstacles, passion for the job keeps many in this career. Some have been ridiculed, snubbed, and publicly humiliated, sometimes by state officials. (Wesley, 2021)

In spite of the early arrival of vaccines, any end to the devastating impact of the impact on the global media industry, journalism and journalists is set to continue for the immediate future. Writing with empathy and flexibility such as the two exemplar Pacific writers present here in this article is an appealing model for crisis communication in the Asia-Pacific region. 


\section{Article 1:}

\section{Pregnant PNG teacher Jerolyn walks $25 \mathrm{~km}$ for her unborn baby - but dies tragically}

\section{By Patrick Angrai}

Jerolyn Arimbandai was the only woman teacher of a newly established Catholic-run high school in the Middle Ramu district of Papua New Guinea's Madang province.

She was married to Steven Arimbandai, a local from Josephstaal, also a teacher at Josephstaal High School. They had a child and were expecting their second.

On June 27, she decided to move to town in preparation for the second birth. Her decision to move to town was due to the fact that the Josephstaal Health Centre had run out of basic medical supplies four months prior.

At eight months

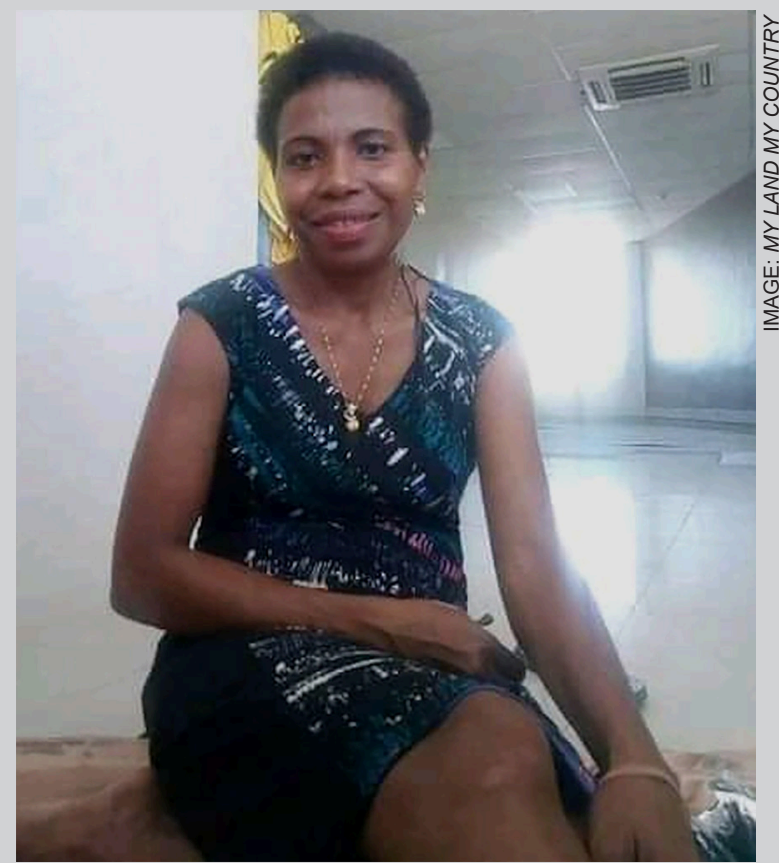

Figure 1: PNG schoolteacher Jerolyn Arimbandai: A tragically fatal journey to hospital in Madang from a remote village.

pregnant, she walked a 25 kilometre road. I was with the group accompanying her when we left Josephstaal at 7:00 am. We reached Guam at 6:30 pm.

She departed for town at 9:00 pm. I couldn't get on the PMV [public motor vehicle] since it was overloaded with passengers and cocoa bags.

At around 4:00am, they reached Bogia when Arimbandai experienced the onset of labour pain and was brought to Bogia Health Centre.

Her delivery was supervised at Bogia centre and she was diagnosed with post-partum haemorrhage. She was than referred to Madang General Hospital in the hope that they would get there in time for doctors to treat her.

\section{Died at the hospital front gate}

She died in front of the Modilon Hospital gate.

Her decision to seek medical assistance elsewhere was due to poor basic government service delivery at Josephstaal.

The people of Josephstaal are still struggling, trying to bring in goods and services. The only government services that are available are health and education. 


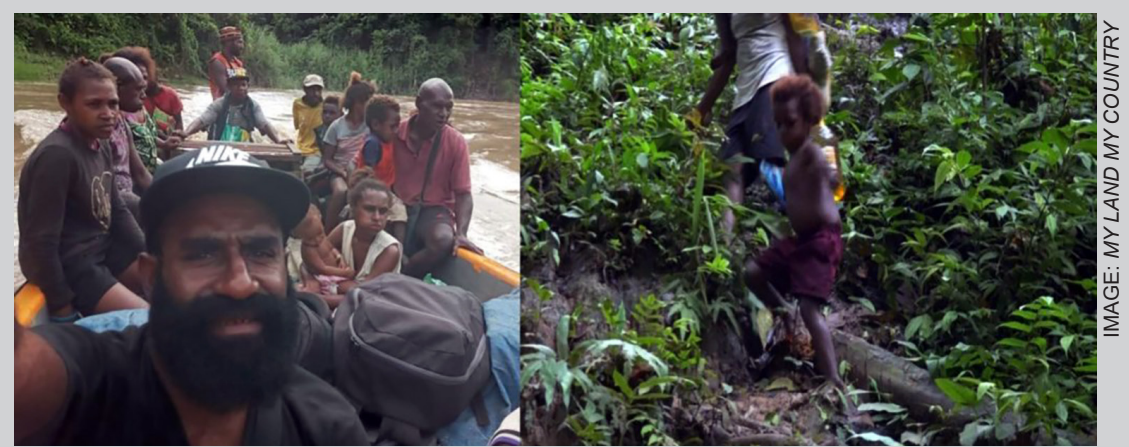

Figure 2: Cameraman Vinansius Wavite travelled to Josephstaal with Patrick Angrai in 2020. They documented the difficulties faced by the Villagers.

All other services are closed.

Health and education are the only "flag raisers" of the province and the nation.

The road is yet to be connected from Guam to Josephstaal. The existing road from the Madang-Sogeram road is now covered with tall grass and shrubs.

To get goods and services to Josephstaal is expensive. The three different payments needed are vehicle hire, boat hire and youth to help.

Sogeram Bridge was washed away by floods in 2019 and is yet to be rebuilt.

There is a mention of road construction from Guam to Josephstaal. The social media updates about the road construction and its progress are all lies.

There has been no progress.

\section{The meaning of the death?}

The Middle Ramu member of Parliament, Johnny Alonk, represents the people of Middle Ramu and Josephstaal is one of the four areas in the district.

What does Jerolyn Arimbandai's death tell us about millions of kina committed to the so-called shopping list request from the K10 million (NZ\$4.1 million) District Services Improvement Programme (DSIP) funds?

Middle Ramu does not have other roads connecting to town. The only road is the Josephstaal road.

Which road is the Middle Ramu MP funding every year while the Josephstaal road continues to deteriorate?

My question to the provincial government: Does this female teacher's death tell you anything about your distribution of funds throughout the entire province?

The people of Josephstaal had so much hope.

Patrick Angrai is a Papua New Guinean health worker. This article was first published on journalist Scott Waide's blog My Land My Country. 


\title{
Article 2:
}

\section{Fiji student son tells of his pregnant nurse mum's losing struggle with COVID-19}

\author{
By Josefa Babitu in Suva
}

The dream of putting a smile on his mother's face on his graduation day from university has become one that will never happen for Gabriel Gade, after his mother succumbed to the coronavirus that has killed dozens of people in Fiji (COVID-19 Dashboard, 2021).

"My ultimate dream was to make her proud of all her sacrifices, battles in life and the love she gave me over the last 21 years of my life," he told Asia Pacific Report.

"My mother had to work all the time to pay off the mortgage, and I could tell that

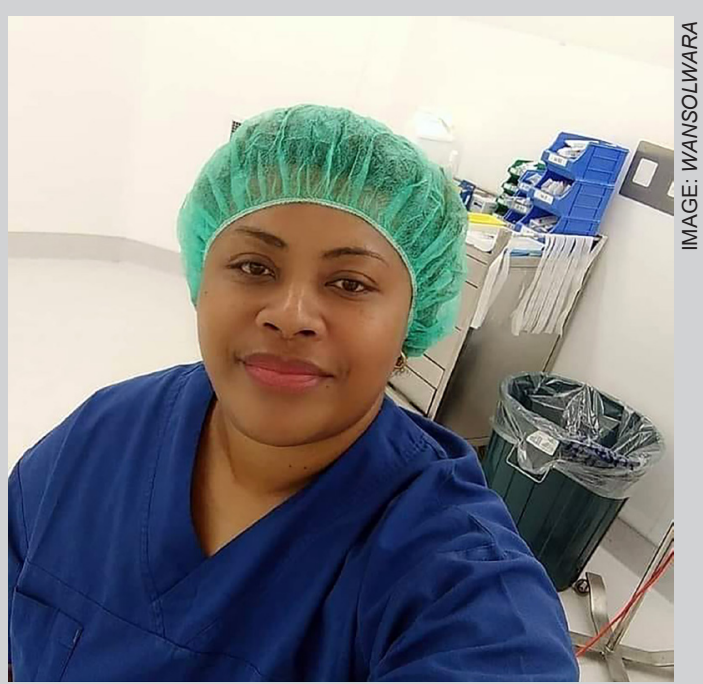

Figure 4: Fiji nurse Suliana Bulavakarua: Dedicated to saving lives but lost her own from COVID-19. she was exhausted most of the time, but I think it was her love for her children that kept her going every day.

His mother, Suliana Bulavakarua, worked as a registered nurse at the Colonial War Memorial Hospital (CWMH) in the capital Suva, the largest healthcare facility in the country, where his family believes she contracted the virus while pregnant.

After she tested positive for COVID-19 on July 16, she was transported to the COVID-care facility in Suva, leaving behind Gade and his sister at home as their father was working outside of the mainland.

Her children also tested positive for the virus but have since recovered. Gade was vaccinated with the first dose of the AstraZeneca vaccine while his mother was awaiting the Moderna vaccine that was to be administered to pregnant women.

Her daughter was not eligible for the vaccine as she was age under 18.

\section{Her condition worsened}

Bulavakarua's condition got worse on July 18 and she was advised by attending physicians to deliver her baby by caesarean section.

The 44-year-old gave life to a baby girl but the battle with COVID-19 was so intense that it soon ended her life.

"It was late at night on Wednesday [July 21] when my phone rang and I did not answer because it was a new number and it was late as well. However, little 
did I know the hospital was calling me to inform us of our mother's passing," says Gade.

"A team from the hospital knocked on our doors on Thursday morning and relayed the news and my sister and I broke into tears. The world suddenly stopped as I lost the one person I owe everything to.

"My mind ran wild but hours later I had to compose myself for my family, especially my sisters who will now grow up without a mother."

The Lau native said the teachings of his mother was something he would hold dear to his heart and would use in the upbringing of his sisters.

"My mother taught me to be generous, loving and to care for people that needed my help.

"I remember a night where I would do my assignments on my study table in our

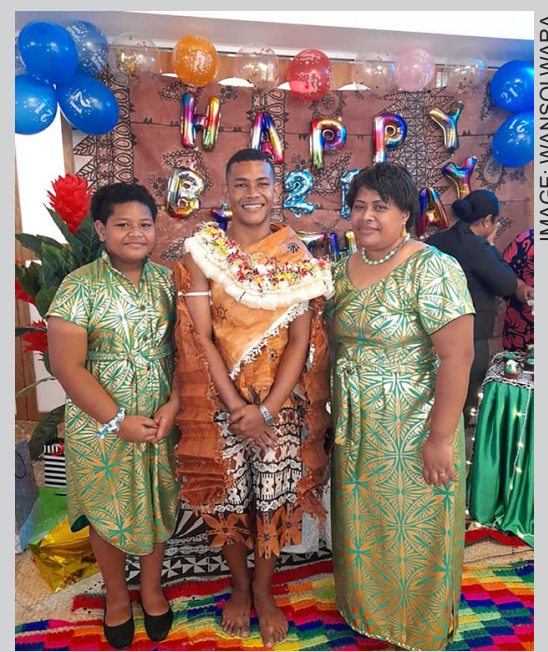

Figure 5: Gabriel Gade with his mother, Suliana Bulavakarua, and sister at the time of his 21st birthday in 2020 living room and during her days off she would sit on the couch, and then she would try to make small talk.

"My mom and I had this relationship where she would always be pressed to do things, like for me to graduate. My mom was always supportive of my endeavours.

"I love you so much mom."

The "fallen hero" is survived by her husband and three children.

\section{Healthcare workers remember fallen hero}

The loss of Bulavakarua was not only for the family, but for healthcare workers around the country as they took to social media to express their feelings.

A nurse posted on Facebook that Bulavakarua was the talk of the operating theatre at the hospital she worked in as they all reminisced about her dedication to saving lives in the country.

Fiji's Health Secretary Dr James Fong, in a televised address, announced the passing of the healthcare worker and said she was one of the many who risked their lives to save people from the deadly delta variant of the virus.

"This current crisis is demonstrating the essential, tireless, innovative and too-often undervalued role of health workers and our frontline colleagues in ensuring strong, resilient health systems for everyone, everywhere," he said.

"They work long hours, sacrifice time with their families, and endure the stresses that this pandemic places upon them as individuals, professionals, and upon the entire health system.

"Delivering health services in an environment of constraint resources will often mean providing access to life saving care at the expense of comfort.

Meanwhile, healthcare workers are currently looking after 17,937 people living with the deadly virus in the nation where 195 people have died. 


\section{References}

Abano, I., \& Kumar, S. (2021, August 11). Irreversable human-caused climate crisis threatens Pacific island nations. Earth Journalism Net. Retrieved on August 15, 12021, from https://earthjournalism.net/stories/irreversible-human-caused-climate-crisisthreatens-pacific-island-nations

Angrai, P. (2021, July 21). Pregnant PNG teacher Jerolyn walks $25 \mathrm{~km}$ for her unborn baby - but dies tragically, Asia Pacific Report. [Republished from the My Land My Country blog under the title 'Health worker, Patrick Angrai, writes a scathing account of poor service delivery in Josephstahl after the death of a young teacher', n.d.] Retrieved on August 15, 2021, from https://asiapacificreport.nz/2021/07/21/ pregnant-png-teacher-jerolyn-walks-25km-for-her-unborn-baby-but-dies-tragically/

Babitu, J. (2021, July 28). Fiji student son tells of his pregnant nurse mum's losing struggle with covid, Asia Pacific Report. Retrieved on August 15, 2021, from https:// asiapacificreport.nz/2021/07/28/fiji-student-son-tells-of-his-pregnant-nurse-mumslosing-struggle-with-covid/

Cass, P. (2020). A common conception of justice underlies Pacific churches' message on climate change . Pacific Journalism Review : Te Koakoa, 26(2), 88-101. https:// doi.org/10.24135/pjr.v26i2.1139

Christians, C. G., Glasser, T., McQuail, D., Nordenstreng, K., White, R. A. (2010). Normative theories of the media: Journalism in democratic societies. Chicago, IL: University of Illinois Press.

COVID-19 Dashboard (2021, August 16). John Hopkins Coronavirus Resource Centre [ 207,273,297 infectious COVID-19 cases and 4,364,409 deaths worldwide]. Retrieved on August 16, 2021, from https://coronavirus.jhu.edu/map.html

Estella, P. G. (2020). Journalism competence and the COVID-19 crisis in Southeast Asia: Toward journalism as a transformative and interdisciplinary enterprise. Pacific Journalism Review : Te Koakoa, 26(2), 15-34. https://doi.org/10.24135/pjr.v26i2.1132

Howes, S., \& Surandiran, S. (2021, June 18). COVID-19 takes hold in the Pacific. DevPolicy, Australian National University. Retrieved on August 17, 2021, from https:// devpolicy.org/covid-19-takes-hold-in-the-pacific-20210618/

Perreault, M. F., \& Perreault, G. P. (2021, February 5). Journalists on COVID-19 journalism: Communication ecology of pandemic reporting. American Behavioural Scientist, 65(7), 976-991.

Robie, D. (2014). Don't spoil my beautiful face: Media, mayhem and human rights in the Pacific. Auckland, NZ: Little Island Press.

Robie, D., \& Krishnamurthi, S. (2020). FRONTLINE: The sociology of a pandemic: Countering a COVID 'disinfodemic' with a campus media initiative. Pacific Journalism Review : Te Koakoa, 26(2), 179-200. https://doi.org/10.24135/pjr.v26i2.1131

Robie, D., \& Marbrook, J. (2020). Bearing witness: A Pacific climate crisis documentary and journalism development project. Asia Pacific Media Educator, 30(1), 77-91. https://doi.org/10.1177/1326365X20945417

Seneviratne, K., \& Muppidi, S. R. N. (2021). COVID-19, racism and politicization: Media in the midst of a pandemic. Newcastle-upon-Tyne, UK: Cambridge Scholars Publishing.

UNRIC Brussels (n.d.). COVID-19: an unprecedented news story for journalists. The United Nations Regional Information Centre (UNRIC), Brussels. Retrieved on August 15, 2021, from https://www.un.org/en/coronavirus/covid-19-journalists-biggest-storytheir-lifetime 
Wesley, F. (2021, May 3). For the public good. The Fiji Times. Retrieved on August 15, 2021, from https://www.fijitimes.com/editorial-comment-for-the-public-good/ Zoonotic diseases and one health in the Asia-Pacific region (2021, July 26). Call for Proposals, Earth Journalism Network. Retrieved on August 15, 2021, from https:// earthjournalism.net/opportunities/zoonotic-diseases-and-one-health-in-the-asiapacific-region

DrDavid Robie is founding editor and currently associate editor of Pacific Journalism Review. He recently retired as director of the Pacific Media Centre at Auckland University of Technology in 2020. He is a former head of journalism at the University of Papua New Guinea and the University of the South Pacific. The author of several books on the Asia-Pacific region and the media, Dr Robie has encouraged project journalism in collaboration with other universities to develop Pacific journalism expertise. The author wishes to thank the collaboration of Scott Waide (PNG) and Josefa Babitu (Fiji) for the writing of this commentary.

tandfonline.com/rmea

@ MediaAsiaJourn

media.asia@amic.asia
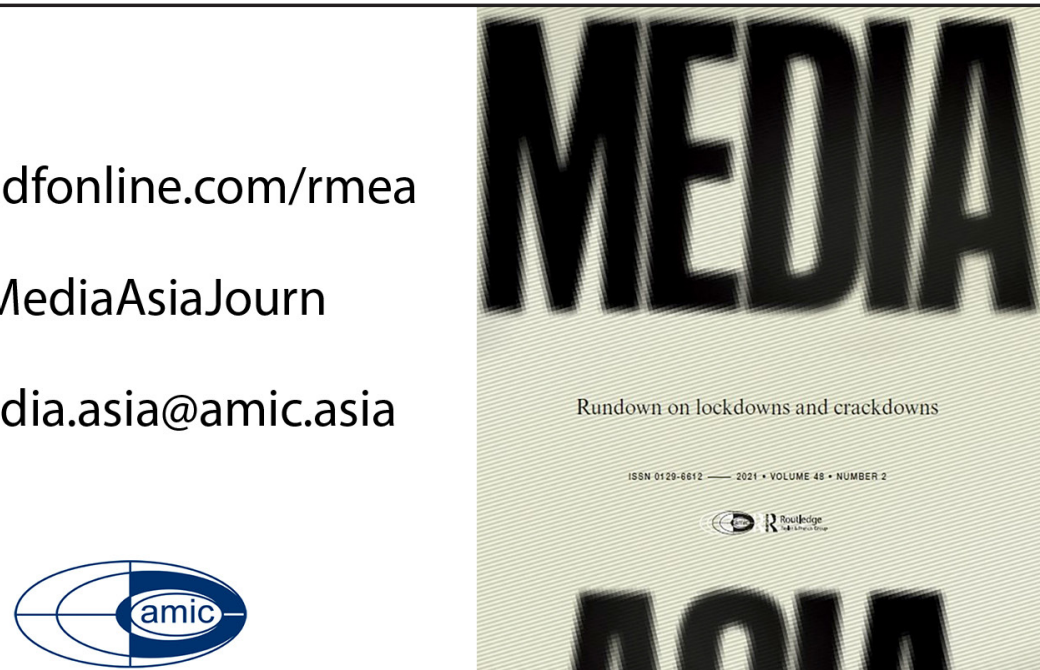

Rundown on lockdowns and crackdowns 15SN 0129.6612 2021. VOLLUME 48 - NUMBER ?

(3) 1R Roukdge

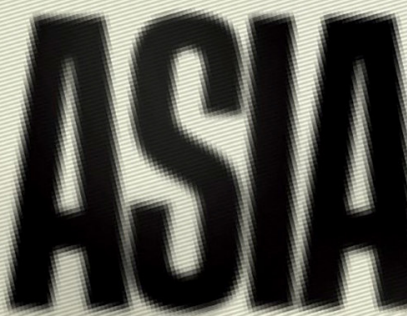

